\title{
Cycle life testing of lithium batteries: The effect of load-leveling
}

\author{
Jingyuan Zhao ${ }^{1,2}$, Yinhan Gao ${ }^{1}$, Jianhua Guo ${ }^{1, *}$, Liang Chu ${ }^{1}$, Andrew F. Burke ${ }^{2, *}$ \\ ${ }^{1}$ State Key Laboratory of Automotive Simulation and Control, Jilin University, Changchun 130022, \\ China \\ ${ }^{2}$ Institute of Transportation Studies, University of California-Davis, CA 95616, USA \\ *E-mail: xhhmail@jlu.edu.cn, afburke@ucdavis.edu
}

doi: $10.20964 / 2018.02 .37$

Received: 28 September 2017 / Accepted: 10 December 2017 / Published: 28 December 2017

\begin{abstract}
In the present study, modules of $\mathrm{LiNiCoAl}$ and $\mathrm{LiFePO}_{4}$ cells were cycled at constant current and on dynamic pulse discharge/charge profiles. All the cycling was done at room temperature. Each module consisted of three 18650 cells. The average current for both discharge profiles was $\mathrm{C} / 2$. The degradation of the modules was tracked in terms of changes in their Ah capacity and resistance as the cycling proceeded. The modules were cycled for about 750 cycles over a period of six months. For both lithium chemistries, the present data indicated that the modules degraded more rapidly with constant current cycling than using the dynamic pulse profiles. This was an unexpected result as current thinking is that load-leveling the discharge of a battery will increase its cycle life. It is difficult to compare the present data with that from the previous studies because the test conditions, charging algorithms, and discharge profiles of the various studies are quite different. The available data in the literature show large variations in the effect of load leveling on the cycle life of batteries.
\end{abstract}

Keywords: Cycle life, degradation, dynamic pulse discharge, constant current discharge, LiNiCoAl, $\mathrm{LiFePO}_{4}$.

\section{$\underline{\text { FULL TEXT }}$}

(C) 2018 The Authors. Published by ESG (www.electrochemsci.org). This article is an open access article distributed under the terms and conditions of the Creative Commons Attribution license (http://creativecommons.org/licenses/by/4.0/). 